\title{
UVODNİ POZNAMKA
}

Přirodní vědy zkoumají realitu objektů odhlížejíce od vlastní historie, která $\mathrm{v}$ tomto smyslu nemá bezprostřední účinek na to, aby-individuum pochopilo a osvojilo si jejich aktuálni stav. Naopak společenské vědy jsou zatím ve stadiu, kdy netvoři všeobecně prujijimaný homogenní systém metod a obecných teorií a $\mathrm{k}$ porozumění jejich jednotlivým směrům a teoretickým proudům je nutno znát jejich historii, onen pưvodní soubor vlivi̊ teoretických a sociálních, který dal vzniknout určitým koncepcím společnosti.

Katedra sociologie se tímto sborníkem pokusila alespoň částečně splatit dluh, který pocituje $v$ tomto kontextu vůči historii sociologie, přičemž ovšem tento sborník není soustředěn jen a pouze jen na historioké problémy, ale má i jiná zaměření.

V intenzívním proudu událostí minulých let jsme však jako instituce i jako jednotlivci věnovali více pozornosti kritice a analýze aktuálních obecných sociologických teorií, metodám sociologie i vyrovnání se $s$ panujícím kvantitativním empirismem než analýze historie jednotlivých osobností, koncepcí i jednotlivých pojmů sociologie.

Provedení takové historické analýzy, a zejména její uvedení do konfrontace s marxistickou koncepcí sociologie a společenských věd vůbec, je úlkolem velmi žádoucím. Náš sborník tento úkol nemůže pochopitelně splnit, je jen prvním pokusem, prvním náznakem cesty a úsilí, které bude nutno $v$ tomto směru vynaložit. 